This is the post print version of the article, which has been published in Irish Historical Studies . 2017, 41(160), 200-220. http://dx.doi.org/10.1017/ihs.2017.32.

\title{
Mobilising for land, nation and class interests: agrarian agitation in Finland and Ireland, 1879-1918
}

Sami Suodenjoki

\begin{abstract}
This article explores the comparative history of land agitation and how it evolved and intersected with nationalism and socialism in Finland and Ireland between the Irish Land War and the Finnish Civil War of 1918. Drawing on current scholarship as well as contemporary newspapers and official records, the article shows that an organised land movement developed later and was markedly less violent in Finland than in Ireland. Moreover, while in Ireland the association of landlordism with British rule helped to fuse the land movement with nationalist mobilisation during the Land War, in Finland the tie between the land movement and nationalism remained weak. This was a consequence of Finnish nationalists' strong affiliation with landowning farmers, which hindered their success in mobilising tenant farmers and agricultural workers. Consequently, the Finnish countryside witnessed a remarkable rise in the socialist movement in the early 1900s. The socialist leanings of the Finnish land movement were greatly influenced by the Russian revolutions, whereas in Ireland militant Fenianism, often emanating from Irish America, affected land agitation more than socialism. As to transnational exchanges, the article also indicates the influence of Irish rural unrest and the related land acts on Finnish public debates and legislation.
\end{abstract}


The land question has played a central part in the national historiographies of both Finland and Ireland. As historians in both countries have noted, the period from the latenineteenth century to the early-twentieth century was marked by fierce debates over the problems of tenant farmers and landless people, the emergence of land movements, and significant changes in landownership. Yet the way in which the land question unfolded in each country differed considerably.

First, the timing of both the agitation and the legislative responses was different. In Ireland, there was a massive land-related mobilisation during the Land War of 187982, whereas in Finland land agitation and protests were considerably smaller in scale until the turn of the twentieth century. Moreover, in Ireland the Land War resulted in immediate legislative reforms related to tenancy, while in Finland legislative changes only emerged in the early-twentieth century. Second, the ability of political movements to canvass support among tenant farmers and agricultural workers was significantly different in these countries. In Victorian Ireland, the nationalist-minded Land League and its successor the National League were able to organise tenant farmers and, to some extent, agricultural workers during and after the Land War. ${ }^{1}$ By contrast, in Finland

\footnotetext{
${ }^{1}$ See Fintan Lane, 'Rural labourers, social change and politics in late nineteenth-century Ireland' in Fintan Lane and Donal Ó Drisceoil (eds), Politics and the Irish working class, 1830-1945 (Houndmills, 2005), pp 124-36; Pádraig C. Lane, 'Agricultural labourers and the land question' in Carla King (ed.), Famine, land and culture in Ireland (Dublin, 2000), pp 104-13; John W. Boyle, 'A marginal figure: the Irish rural labourer' in Samuel W. Clark and James S. Donnelly, Jr. (eds), Irish peasants: violence \& political unrest, 1780-1914 (Dublin, 1983), pp 327-34; Pamela R. Horn, 'The
} 
tenant farmers and rural workers lacked organisations and organs for voicing their grievances until the rise of the socialist labour movement at the beginning of the twentieth century. ${ }^{2}$ Consequently, the Finnish land movement acquired a considerably more socialist character than its Irish counterpart.

This article examines the development of the land movement and its intersection with political ideologies comparatively within the wider imperial frameworks of both countries. In particular, it explores why the land movements were channelled into nationalism in Ireland and socialism in Finland. The analysis focuses on key selected themes that influenced the path taken by the land movements in each country, in particular, imperial policies and different patterns of land ownership. As a result, the article can only touch on the regional variation of agrarian agitation within each country or the complex political role of the Lutheran church in Finland and the Catholic church in Ireland, which must be developed through further research and dedicated studies.

The first section of the article briefly discusses the historiography of rural unrest and land agitation in Finland and Ireland. The second points out some significant similarities and differences in the social and political contexts of each country. The third

National Agricultural Labourers' Union in Ireland, 1873-9' in I.H.S., xvii, no. 67 (Mar. 1971), pp 350-1.

${ }^{2}$ See David Kirby, 'The labour movement' in Max Engman and David Kirby (eds), Finland: people, nation, state (London, 1989), pp 196-7, 201-04; Risto Alapuro, State and revolution in Finland (Berkeley, 1988), pp 117-20; Hannu Soikkanen, 'Revisionism, reformism and the Finnish labour movement before the First World War' in Scandinavian Journal of History, iii (1987), pp 353-5. 
section focuses on the scale and timing of the rural unrest, and the fourth elucidates the repertoire of agrarian protest in both countries. These sections also acknowledge the role of political transfer, that is, the migration of political practices across national borders, in moulding the land movements. ${ }^{3}$ Finally, the concluding section addresses the rise of socialism in the Finnish countryside and its lack of success in rural Ireland. Ultimately, the article illustrates that the political paths taken by land agitation in each country were intricately influenced by international developments and transfers, together with local social structures and institutions.

\section{I}

The land struggle in Ireland in the late-nineteenth and early-twentieth centuries has received extensive scholarly attention since Michael Davitt's The fall of feudalism in Ireland was published in $1904 .^{4}$ The Land War in particular - but also the political mobilisation and agrarian unrest during the following decades - have been scrutinised closely. ${ }^{5}$ The emphasis of the research has long been on the connection between the

\footnotetext{
${ }^{3}$ See Henk te Velde, 'Political transfer: an introduction' in European Review of
} History: Revue européenne d'histoire, xii, no. 2 (July 2005), pp 205-21.

${ }^{4}$ Michael Davitt, The fall of feudalism in Ireland, or, the story of the Land League revolution (London, 1904). For recent research see Brian Casey (ed.), Defying the law of the land: agrarian radicals in Irish history (Dublin, 2013); Fergus Campbell and Tony Varley (eds), Land questions in modern Ireland (Manchester, 2013).

${ }^{5}$ The period following the Land War has been covered, e.g., by David Fitzpatrick, Politics and Irish life 1913-1921: provincial experience of war and revolution (Dublin, 
land movement and the nationalist movement, and on the conflicts and interplay between tenant farmers, landlords, and the state. ${ }^{6}$ Since the 1970 s, the traditional view of the Land War as the Irish people's mass insurrection against alien oppressors has increasingly given way to studies on the social origins of the land movement and the tensions within it. ${ }^{7}$ The historiography has discussed, for example, the decisive role of the alliance between tenant farmers and middle-class town dwellers during the Land War mobilisation. ${ }^{8}$ Some research has also been devoted to the collective action of rural

1977); Fergus Campbell, Land and revolution: nationalist politics in the west of Ireland, 1891-1921 (Oxford, 2005).

${ }^{6}$ James S. Donnelly, Jr., The land and the people of nineteenth-century Cork (London, 1975); Donald E. Jordan, Jr., Land and popular politics in Ireland: county Mayo from the plantation to the Land War (Cambridge, 1994); W. E. Vaughan, Landlords and tenants in mid-Victorian Ireland (Oxford, 1994).

${ }^{7}$ Two seminal studies are Samuel Clark, Social origins of the Land War (Princeton, 1979) and Paul Bew, Land and the national question in Ireland, 1858-82 (Dublin, 1979), which take different positions on the development of the Land War. Clark argues that social and class antagonisms softened in post-famine Ireland, creating an atmosphere where a united peasantry could be mobilised against landlordism, whereas Bew argues that discord rather than unity marked the land movement that was based on volatile 'class alliance' between large and small farmers.

${ }^{8}$ Samuel Clark, 'Strange bedfellows? The Land League alliances' in Campbell and Varley (eds), Land questions, pp 87-116; Brian Casey, 'Matt Harris and the Irish land question, 1876-1882' in Rural History, xxv, no. 2 (2014), pp 183-201. 
workers and their antagonism with tenant farmers during the land struggle. This material seriously undermined traditional perceptions that rural labourers lacked political significance in Ireland prior to independence. ${ }^{9}$

In Finland, the historiography relating to land agitation has long recognised the growing social tension between the landowning and the landless population in the late nineteenth century. Moreover, scholars have increasingly recognised that tenant farmers, as in Ireland, were a core group in the land struggle. ${ }^{10}$ The role of Finnish tenant farmers in the national consolidation and political turbulence received wide public attention particularly after Väinö Linna published his novel trilogy Under the North Star [Täällä Pohjantähden alla] in 1959-62. The trilogy follows the life of a tenant farmer family, living in south-western Finland, from the late-nineteenth century through the political turmoil of 1905-07, the Civil War of 1918, and the Second World War. After its publication, the second novel in particular caused controversy because it showed sympathy towards the tenants and labourers who joined the socialist movement and fought in the ranks of the Reds in the Civil War. As such, it challenged dominant historical ideas about the origins of the Civil War and had considerable impact on the popular view of Finnish history. Academic historiography was also affected, and Linna's novels were soon followed by several studies that reassessed the

\footnotetext{
${ }^{9}$ Lane, 'Rural labourers', pp 113-17.

${ }^{10}$ Jaakko Forsman, Mistä syystä sosialismi levisi Suomen maalaisväestön keskuuteen? (Helsinki, 1912).
} 
conditions of tenant farmers and the role of land agitation in the rise of socialism and revolutionary mobilisation. ${ }^{11}$

Regarding the period preceding the rise of the labour movement, however, the manifestations of class conflict and social unrest in rural Finland have received relatively little scholarly attention. The scarcity of research contrasts sharply with the extensive historical interest in the Land War and the subsequent rural unrest in Ireland. The lack of research in Finland stems partly from the fact that no massive protest movements similar to the ones in Ireland occurred in the Finnish countryside. However, this does not mean that the late nineteenth-century Finnish countryside could be characterised as tranquil and harmonious. While violent rioting was almost nonexistent, this article will nevertheless emphasise that visible conflicts occurred in rural Finland at the end of the nineteenth century.

${ }^{11}$ Viljo Rasila, Suomen torpparikysymys vuoteen 1909 (Helsinki, 1961); Hannu Soikkanen, Sosialismin tulo Suomeen (Porvoo, 1961); Viljo Rasila, Kansalaissodan sosiaalinen tausta (Helsinki, 1968); Pekka Haatanen, Suomen maalaisköyhälistö tutkimusten ja kaunokirjallisuuden valossa (Porvoo, 1968); Viljo Rasila, Torpparikysymyksen ratkaisuvaihe: Suomen torpparikysymys vuosina 1909-1918 (Helsinki, 1970); Arvo Santonen, Pienviljelijäin järjestäytymiskysymys ja pienviljelijäjärjestöjen vakiintuminen Suomessa: tutkimus maatalouden pienviljelyspoliittisesta murrosvaiheesta 1930-luvun alkuun mennessä (Helsinki, 1971). 
Finland and Ireland were overwhelmingly agrarian countries in the late-nineteenth and early-twentieth centuries. In 1890, no less than 90 per cent of the Finnish population lived in the countryside and 70 per cent of the economically active population was engaged in agriculture and forestry. ${ }^{12}$ Ireland was also predominantly agrarian, but the rural population had shrunk rapidly in the course of the nineteenth century. The number of people living in rural areas and small towns had declined from seven million to three million in Ireland between the Great Famine and the First World War. ${ }^{13}$ There was a marked decline in the number of labourers; according to John W. Boyle's estimate, the number of male agricultural labourers decreased by 73 per cent - from 1.1 million to 295,000 - between 1841 and 1901, and the fall in numbers continued during the first decade of the twentieth century. ${ }^{14}$

The decline of the Irish agrarian proletariat stood in sharp contrast to the Finnish countryside, where the landless population expanded during the late-nineteenth century so that agricultural labourers formed around 40 per cent of the people working in agriculture at the turn of the twentieth century. As this part of the population was not effectively absorbed into industry, there was a wide public debate about the resulting

\footnotetext{
${ }^{12}$ Annuaire Statistique de Finlande, 1909 (Helsinki, 1909), p. 7; Population by industry: population by industry and commune in 1880-1975 (Helsinki, 1979), p. 333. ${ }^{13}$ Cormac Ó Gráda, Ireland: a new economic history, 1780-1939 (Oxford, 1994), pp 213-14.

${ }^{14}$ Boyle, 'Irish rural laborer', 312.
} 
rural overspill and the conditions of the rural working class in Finland. ${ }^{15}$ It can be argued that the opposite trends in the quantity of the agrarian proletariat in Finland and Ireland inevitably affected the nature of land agitation and political organisation in each country.

Finland and Ireland differed considerably also in their relationship with the imperial centre. Finland had been annexed to Russia as a grand duchy in 1809 , and, in the late-nineteenth century, it had more governmental and financial autonomy than any other part of the Russian empire. The grand duchy had a separate central administration, which operated under the surveillance of the governor-general appointed by the Russian Tsar, and a representative assembly known as the Diet. ${ }^{16}$ Moreover, Finland had its own currency and budget and it even formed a separate customs area. Owing to these privileges, Finnish nationalists had less need to fight for separate status or to openly challenge imperial rule. Rather, the nationalists could display loyalty to Russia without

${ }^{15}$ Ann-Catrin Östman, 'Mekanisoinnin ensimmäinen aalto' in Matti Peltonen (ed.), Suomen maatalouden historia II (Helsinki, 2004), p. 55; Pertti Haapala, Kun yhteiskunta hajosi: Suomi 1914-1920 (Helsinki, 1995), pp 77-9, 102-03; Alapuro, State, 47.

16 The Diet consisted of four chambers: nobility, clergy, bourgeoisie and peasantry. The peasant chamber was elected in an indirect election, in which the vote was restricted to landowners, who formed only 4.5 per cent of the rural population at the beginning of the twentieth century (Jouko Vahtola, Suomen historia (Helsinki, 2003), pp 259-61). 
fundamentally compromising their programme of strengthening the already-existing state and the status of the Finnish language. ${ }^{17}$

In Victorian Ireland, the circumstances were very different, not least because of a lesser degree of autonomy. Although a characterisation of Ireland as simply a victim of British imperialism is too simplistic in trying to grasp the complexity of the BritishIrish relationship under the union, it can be argued that the imperial context, particularly its influence on land ownership, had a greater impact on the development Irish nationalism than on its Finnish counterpart, at least until the turn of the twentieth century. Consequently, a militant and anti-imperial form of nationalism gained a foothold in Ireland considerably earlier than in Finland. ${ }^{18}$ This militancy was manifested in the Fenian society, which struggled for Irish independence and had strong support in Irish America. ${ }^{19}$

The radical form of nationalism also had a profound impact on the land movement in Ireland. Irish nationalists used the land question effectively as a weapon in their struggle against British rule by pinning the blame for the problems of

${ }^{17}$ Cf. Alapuro, State, pp 90, 96, 111; Bill Kissane, 'Nineteenth-century nationalism in Finland and Ireland: a comparative analysis' in Nationalism and Ethnic Politics, vi (2000), pp 30-4.

${ }^{18}$ For debates on the Irish relationship to empire, see Stephen Howe, 'Colonized and Colonizers: Ireland in the British Empire' in Alvin Jackson (ed.), The Oxford handbook of modern Irish history (Oxford, 2014), pp 65-82.

${ }^{19}$ On Fenianism see, e.g., Patrick Steward and Bryan McGovern, The Fenians: Irish rebellion in thenNorth Atlantic world, 1858-1876 (Knoxville, 2013). 
landownership on imperial policies. ${ }^{20}$ Using this strategy, they were successful in canvassing support among tenant farmers who sought protection from eviction and a significant section of labourers who wanted access to land. One reason why the nationalists had little difficulty in linking the land question with the cause of Ireland was the popular image of the landlords being absentee English Protestants or at least as having strong material and personal ties to England. ${ }^{21}$ As Michael Davitt, the prominent nationalist and former Fenian, put it, landlords were 'the political garrison of England in Ireland, equipped with every weapon and resource at the disposal of a great empire for their protection' ${ }^{22}$

The landed gentry was also criticised by nationalists and social liberals in Finland in the late-nineteenth century. ${ }^{23}$ However, Finnish nationalists could not attack the landed aristocracy on the same grounds as their Irish counterparts because Finnish landed noblemen, unlike their Irish equivalents, did not identify politically and culturally with the metropolitan power. Moreover, unlike in Ireland, the power of the

${ }^{20}$ Paul Bew and Patrick Maume, 'Michael Davitt and the personality of the Irish agrarian revolution' in Fintan Lane and Andrew G. Newby (eds), Michael Davitt: new perspectives (Dublin, 2009), pp 66-8.

${ }^{21}$ Michael J. Winstanley, Ireland and the land question, 1800-1922 (London, 1984), pp 11-12; L. Perry Curtis Jr., 'Demonising the Irish landlords since the Famine' in Casey (ed.), Defying, pp 24-7.

${ }^{22}$ Davitt, Fall, p. xvii.

${ }^{23}$ See Marja Vuorinen, Kuviteltu aatelismies: aateluus viholliskuvana ja itseymmärryksenä 1800-luvun Suomessa (Helsinki, 2010), pp 379-80, 394-7. 
Finnish nobility was based less on land and more on occupying central positions in the state administration. Although there were noblemen who held significant estates, particularly in south-western Finland, as a whole the landownership of the gentry declined during the nineteenth century. ${ }^{24}$ This made it hard for the social reformists to the blame the gentry for the problems of landownership.

On the whole, landownership was far less concentrated in Finland than in Ireland. In 1910, only 9 per cent of the total arable land in Finland belonged to large estates with a minimum of 100 hectares of arable land, while a half of the arable land belonged to middle-size farms with 10-50 hectares. Most of these middle-size farms were freeholds, whereas a great majority of leaseholds involved less than 10 hectares of arable land. ${ }^{25}$ The landowning farmers also owned most of the best forests and thus benefitted greatly from the forestry-based industrialisation that started in the latenineteenth century. The improved economic position of the freeholders was accompanied by their growing influence in local and national politics; this was due to the reform of local government and the beginning of the regular assemblies of the Diet in the 1860s. At the same time, the freeholders became the backbone of the nationalist movement, which strove for a Finland united in language and culture. ${ }^{26}$ This close link

\footnotetext{
${ }^{24}$ Alapuro, State, pp 90-1, 95; Alex Snellman, 'Suurtilat ja Suomen aateli 1800-1900luvuilla' in Ennen ja nyt, ii (2012), (http://www.ennenjanyt.net/?p=605) (28 May 2014). 25 'Superficie des champs, répartie en exploitations de grandeur différente, de propriétaires et de fermiers, en 1910' in Annuaire Statistique de Finlande (Helsinki, 1915), pp 120-1. The figures include both freeholdings and tenant farms.

${ }^{26}$ Alapuro, State, pp 36, 42-3, 94-5.
} 
between nationalism and freeholders had important consequences regarding land agitation, since it undermined nationalists' interest in pursuing radical land reform.

III

The problems of landownership and tenancy attracted increasing publicity in the Grand Duchy of Finland in the early 1880s. The main reason for this was the unrest that appeared among tenant farmers and rural labourers in several regions. Disturbances surfaced, for example, at the manor of Kellahti in western Finland, where rumours about forthcoming land redistribution began circulating among the tenants during the summer of 1882 . These rumours encouraged some of the tenants to refuse to pay their rent to the landlord, whereupon they were evicted. As the evictions were followed by arson attacks on the manor's property, some newspapers suggested that the tenants had used arson to retaliate against their evictor. The reporters were particularly shocked by the fact that the landowner on whose estates these acts were committed was Edvin Avellan, a peasant representative of the Diet and a well-known agricultural reformer. The reporters therefore viewed the tenants' actions as sublime ignorance and barbarity, and even associated the actions with the contagion of socialist ideas among the tenants. $^{27}$

Apart from Kellahti, signs of discontent occurred particularly in south-western Häme, where tenant farmers from several estates petitioned the governor-general in the spring of 1882. In their petitions, the tenants complained about their harsh treatment or unjust eviction by the landowners and asked the state to redeem the ownership of the

${ }^{27}$ Satakunta, 5 Aug. 1882; Ilmarinen, 22 Aug. 1882; Satakunta, 26 Aug. 1882. 
land that they cultivated. Behind this request was the petitioners' hope that by becoming leaseholders of state-owned lands they could more easily redeem the lands for themselves. $^{28}$ The government did not respond to the tenants' claims, but their mobilisation was acknowledged in the ongoing proceedings of the Diet and it aroused press interest in the tenant farmers' conditions. Thus, tenancy questions became increasingly politicised in the grand duchy. ${ }^{29}$

The Finnish rural disturbances of the early 1880 s occurred at the same time as larger agrarian protest movements elsewhere in Europe. In Russia, there had been several waves of land redistribution rumours and peasant rebellions in the late $1870 \mathrm{~s}$ and early 1880 s. These rebellions had been influenced by revolutionary movements such as the so-called Land and Liberty (Zemlya i Volya) and Black Repartition (Cherny Peredel), which demanded the transfer of all lands into the hands of the rural working class. ${ }^{30}$ As the aims of these movements had some similarities to the demands presented by Finnish tenants in 1882, some reporters eagerly viewed the Finnish protests as indications of the spread of Russian 'nihilism' or the Zemlya i Volya movement to

\footnotetext{
${ }^{28}$ Tenants of Matku to the Governor-General, 24 Feb. 1882 (National Archives of Finland (N.A.F.), Chancellery of the Governor-General (KKK) 1882, Fb:1482, d. 29); Hämäläinen, 18 Mar. 1882; Hämeen Sanomat, 21 Mar. 1882.

${ }^{29}$ Rasila, Suomen torpparikysymys, pp 98-9.

${ }^{30}$ For Zemlya i Volya and Cherny Peredel see, e.g., Franco Venturi, Roots of revolution: a history of the populist and socialist movements in 19th century Russia (London, 2001 [1960]), 558-708.
} 
Finland. ${ }^{31}$ Given that Finnish rural protests had no organisational link with the Russian revolutionaries, such views were ill-founded. To argue, however, that the Finnish protests were completely disconnected from events in Russia would be unwise, because news of the Russian revolutionary movements may well have indirectly inspired Finnish rural inhabitants.

Beyond Russia, agrarian protests appeared simultaneously in other areas of Europe as well. ${ }^{32}$ Particularly notable among these was the Irish Land War, which erupted in 1879 and led to the emergence of the Land League as a mass organisation campaigning for tenant rights. Nominally, the Land War ended in 1882 after the British government had adopted coercive policies and imprisoned many Land League leaders. ${ }^{33}$ Nonetheless, the rural unrest continued thereafter and in 1886, the so-called Plan of Campaign launched a new wave of agitation and rent strikes across Ireland. During this period, landless labourers were increasingly engaged in collective action to advance their interests, which had been left largely unsatisfied by the Land War. The rural workers' movement was, however, eventually amalgamated with the National League,

${ }^{31}$ Hämäläinen, 18 Mar. 1882; Ilmarinen, 22 Aug. 1882.

${ }^{32}$ On rural unrest in Italy in the mid-1880s see John A. Davis, Conflict and control: law and order in nineteenth-century Italy (Atlantic Highlands, 1991), pp 205-09; on Spain during the 1870s, see Murray Bookchin, The Spanish anarchists: the heroic years 1868-1936 (New York, 1977), pp 91-108; on the Crofters' War in Scotland, see Andrew Newby, 'Land and the "crofter question” in nineteenth-century Scotland' in International Review of Scottish Studies, xxxv (2010), pp 7-36.

${ }^{33}$ On the arrests of Land League leaders, see Bew, Land, pp 154, 170, 194-6. 
which was formed by former Land Leaguers to promote Home Rule, enfranchisement, and economic reforms. This amalgamation meant that rural workers had to adjust to the subordination of their class interests to the 'national interest', or to a pan-class alliance, which essentially undermined labour militancy. ${ }^{34}$

On the whole, the Irish historiography has viewed the Irish countryside at the end of the nineteenth century as a place of intense agitation and restlessness. This view stands in sharp contrast with the idyllic image of the Finnish countryside during the same period. Even if there were rural disturbances in Finland in 1882 and occasional collective action by tenant farmers in the following years, all of these events essentially remained local or regional and failed to evolve into an organised movement. ${ }^{35}$ This was due to the lack of newspapers, agrarian organisations and political groups, which would have taken up the cause of tenant farmers and rural workers, and enhanced their nationwide mobilisation.

A crisis in Finno-Russian relations was necessary for the rural unrest to become more widespread in Finland. In February 1899, Tsar Nicholas II declared an imperial manifesto that limited the Finnish Diet's influence in the implementation of imperial legislation in Finland. From the Finnish nationalists' perspective, the manifesto flagrantly violated the autonomy of the Grand Duchy. Therefore, the nationalists organised peaceful mass opposition, which was symbolised by the so-called Great Address, a petition with half a million signatures that was addressed to the Tsar for the

\footnotetext{
${ }^{34}$ Lane, 'Rural labourers', pp 129-36.

${ }^{35}$ See Rasila, Suomen torpparikysymys, pp 91-3, 128-35.
} 
repeal of the February Manifesto and for the preservation of the legislative powers of the Diet. ${ }^{36}$

Finnish historiography has viewed the Great Address as an indication of the Finnish people's uniform opposition to the imperial integration policies. In many rural areas, however, tenant farmers and labourers were reluctant to sign the Great Address and thus avoided taking sides in the conflict between the Russian government and Finnish nationalists. By doing so, they did not necessarily align themselves consciously with Tsarist rule and against the nationalist agenda, but rather protested against the failure of the nationalist elite to sufficiently address the problems of tenancy and working conditions. ${ }^{37}$ No one articulated this mood of protest more clearly than a few tenants from Lohja, who shunned the Great Address by stating to two landowners: 'let the Russian law come, it cannot make our status worse than it is now, but it will rob your great prestige and show that every master has his master, too' ${ }^{38}$

The spring of 1899 also witnessed a new wave of rumours, or improvised news, among Finnish tenant farmers and rural workers. According to contemporary observers, the rumours had it that the tsar was about to implement nationwide land redistribution which would provide tenant farmers and agricultural labourers with a plot of arable land

\footnotetext{
${ }^{36}$ For the Great Address see Päiviö Tommila, Suuri adressi (Porvoo, 1999).

${ }^{37}$ C. Leonard Lundin, 'Finland' in Edvard C. Thaden (ed.), Russification in the Baltic provinces and Finland, 1855-1914 (Princeton, 1981), pp 425, 429; Matti Peltonen,
} Talolliset ja torpparit (Helsinki, 1992), pp 258-9.

${ }^{38}$ Mathilda Grönqvist's account 'Viime vuoden tapahtumia', 1900, p. 2:2 (Finnish Literature Society, Matilda Grönqvist's papers). 
free of charge or for an affordable price. ${ }^{39}$ The nationwide scope of these rumours alarmed nationalist intellectuals, who recognised that the rumours could weaken popular opposition to imperial policies. Thus, the nationalists campaigned to suppress the rumours by publishing scores of newspaper articles and pamphlets and by sending educators to instruct rural people. This campaign helped to mute the rumours by the summer of 1899 , but it did not curb the growing social dissonance, which soon found new outlets. ${ }^{40}$

The discontent within the Finnish countryside manifested itself, for example, in the increasing number of petitions and complaints submitted to the governor-general's office between 1899 and 1905. Many of these came from tenant farmers or labourers who wanted the governor-general to revoke their eviction or to grant them a loan to purchase a farm. Others hoped the government would improve their housing or working conditions. What was common to most petitioners was that they laced their letters with

${ }^{39}$ K. J. Ståhlberg, Berättelse om verkstäld undersökning angående utspridande af falska rykten i landet (Helsingfors, 1899), pp 3-6; Sami Suodenjoki, Kuriton suutari ja kiistämisen rajat: työväenliikkeen läpimurto hämäläisessä maalaisyhteisössä 1899_ 1909 (Helsinki, 2010), pp 96-7.

${ }^{40}$ For an example of the anti-rumour propaganda, see a song leaflet composed under the pseudonym Tuomas Totinen, Laulu maanjakohommista eli kuinka Jukolan Jussin kävi (Pori, 1899). See also Peltonen, Talolliset, pp 262-3. 
expressions of loyalty to the tsar and with denunciations concerning anti-government activity in their surroundings. ${ }^{41}$

The governor-general, who presided over the Finnish Senate but ultimately represented the Tsarist rule, welcomed petitions and denunciations from the Finnish countryside as indications of popular support for imperial rule. In fact, he used these 'voices from below' eagerly to present the Tsarist regime as a defender of Finnish paupers against the oppressive Finnish upper class. The governor-general also sought to enhance the Russian government's image among the Finnish rural poor by steering some funds to buy large estates and to divide them among their tenants. ${ }^{42}$ On the whole, however, the governor-general's measures to improve the conditions of the landless or to facilitate the transfer of lands to the occupants remained meagre at the beginning of the twentieth century. Even the new land lease act, which was introduced in 1902, failed to improve the security of tenants in Finland. As Tuomo Polvinen states, truly significant reforms in the conditions of tenant farmers and agricultural labourers would have required a revision of property rights, but the tsarist regime was too inefficient and

\footnotetext{
${ }^{41}$ Sami Suodenjoki, 'Ilmianto valvonnan ilmapiirin lietsojana routavuosien Suomessa' in Historiallinen Aikakauskirja 111 (2014), pp 145-9; idem, 'Whistleblowing from below: Finnish rural inhabitants' letters to the imperial power at the turn of the twentieth century' in Ann-Catrine Edlund, Lars-Erik Edlund and Susanne Haugen (eds), Vernacular literacies - past, present and future (Umeå, 2014), pp 278-80.

${ }^{42}$ Tuomo Polvinen, Imperial borderland: Bobrikov and the attempted Russification of Finland 1898-1904 (London, 1995), pp 229-31. On the impact of the land act of 1902, see Rasila, Suomen torpparikysymys, pp 226-30.
} 
conservative to go so far. Thus, the regime was ultimately unable to assuage the tenants' and workers' discontent and these groups were forced to look in other directions for a solution to their problems. ${ }^{43}$

In 1903, the agrarian discontent in Finland found a new outlet: the strike. On several large estates, mainly in south-western Finland, tenant farmers and farm labourers went on strike or threatened to strike in order to shorten their working days. Among these estates were the manor of Jokioinen and the agricultural school of Mustiala, which had witnessed tenant's protests already in 1882. Most of the strikes were successful, as they occurred during the period of sowing or harvesting, and therefore forced employers to concede to the labourers' demands. Moreover, the strikes frightened numerous other landowners into cutting their labourers' working hours even before it was demanded by their own tenants and workers. ${ }^{44}$

Apart from the strikes in south-western regions, few open conflicts occurred in the Finnish countryside during the earliest years of the twentieth century. Even the severe crop failure of 1902 - which worsened landless people's conditions, particularly in northern Finland - did not lead to restlessness among destitute rural labourers. This tranquillity stood in contrast with the cities, where the food shortage led to substantial protests by unemployed people. These protests were fuelled by the emergent labour newspapers, which considered the scarcity of food to be a fault of the social order,

${ }^{43}$ Polvinen, Imperial borderland, p. 232; Matti Peltonen, 'Epävarmuus ja viha: Torpparikysymyksen moraalitalous' in Raimo Parikka (ed.), Työ ja työttömyys (Tampere, 1994), pp 319-21.

${ }^{44}$ Rasila, Suomen torpparikysymys, pp 258-63, 271-9. 
blamed landowners for profiteering, and argued for land reform. ${ }^{45}$ At this point, however, labour agitation had little resonance in rural areas outside the southern provinces.

The preconditions for the rise of the labour movement in the countryside were fundamentally changed when the revolutionary turbulence in Russia extended to Finland in 1905. The revolution took the form of a general strike that started on 29 October. During the strike, crowds across the grand duchy demonstrated against the assimilative and suppressive policies launched by the imperial government in the preceding years and called for democratic reforms. As a result, the tsar consented to suspend administrative integration, to restore civil liberties, and to promise universal and equal suffrage in parliamentary elections. This ended the strike officially on 6 November, although the unrest continued in many areas. ${ }^{46}$

The immediate aims of the general strike had little to do with the question of land, but as communications were halted during the period of the strike, rural inhabitants suffered a news blackout and were thus left with only a vague understanding of events. This created the circumstances in which land redistribution rumours

\footnotetext{
${ }^{45}$ Antti Häkkinen, 'Nälkä punikkina? Huonot ajat ja poliittinen aktiivisuus' in Matti Peltonen (ed.), Arki ja murros: tutkielmia keisariajan lopun Suomesta (Helsinki, 1990), pp 429-33.

${ }^{46}$ On the general strike, see Marko Tikka, Kun kansa leikki kuningasta: Suomen suuri lakko 1905 (Helsinki, 2009).
} 
resurfaced ${ }^{47}$ In the province of Häme, for example, the press reported on tenants who noted 'that in Russia the land has been taken away from the rich and divided equally among the poor, and the same will happen here as well' ${ }^{48}$ Such reports indicate that the strike, with its prospects of democracy and societal change, inspired the rural poor to highlight the importance of landownership reforms and to apply pressure on the authorities once more through rumour spreading. Besides rumours, the general strike also stirred more radical and organised activity among the rural working class. In the manor of Vuojoki, for example, tenant farmers went on strike to improve their rental terms and conditions in November 1905. The strike led to evictions and involved a violent clash between strike-breakers and picketers, after which some picketers were imprisoned.$^{49}$ Likewise, the radicalisation of tenants' and workers' behaviour characterised the numerous other agricultural strikes that broke out in unprecedented numbers in Finland in the following two years. ${ }^{50}$ From 1908 onwards, strike activity by rural workers faded away. A new wave of agricultural strikes did not occur in Finland until the revolutionary year of 1917, when day-labourers tried to extend the eight-hour

${ }^{47}$ Sami Suodenjoki, 'Suurlakon riitaisa yksimielisyys' in Pertti Haapala et al. (eds), Kansa kaikkivaltias: suurlakko Suomessa 1905 (Helsinki, 2008), pp 111-14. ${ }^{48}$ Aamulehti, 30 Nov. 1905.

${ }^{49}$ Matti Peltonen, 'Vuojoen kartanon lakko vuonna 1905: Suurlakon aikaista radikalismia Lounais-Suomessa' in Peltonen (ed.), Arki ja murros, pp 253-78. ${ }^{50}$ Työtilastollinen Aikakauslehti (1907), p. 97; Soikkanen, Sosialismin tulo, pp 316-17. 
working day to agricultural work. ${ }^{51}$ Tenant farmers also joined some of these strikes, as many of them paid rent by working a certain number of days for the landowner. On the other hand, some tenant farmers were employers themselves and therefore did not benefit from the strikes. ${ }^{52}$

In general, the relationship between the tenant farmers and the landowners remained tense after 1905. Even though a new land lease act was enacted in 1909, it failed to improve the status of tenant farmers and the security of tenancy. According to the act, landowners were obliged to compensate the tenants for the improvements the tenants had made to the farm, but this obligation only concerned improvements that were made after the law had been introduced. This made eviction a tempting option for landowners, because by evicting their tenants they could avoid the forthcoming compensation. A few years after the new act, at least 14,000 tenant families were evicted from their farms and around 60,000 families were in danger of being evicted. These figures can be compared to the eviction levels in Ireland, where an average of 3,218 evictions were carried out yearly in 1879-88. In both countries, evictions or the threat of widespread eviction also acted as a spur for political action, albeit in different ways. In the Finnish case, the insecurity made the tenantry increasingly distrustful of

${ }^{51}$ Työtilastollinen Aikakauslehti (1908), pp 226-7; ibid. (1909), pp 327-8; ibid. (1910), pp 313-14; ibid. (1911), pp 141-2.

${ }^{52}$ Rasila, Torpparikysymyksen ratkaisuvaihe, 272-280. 
political decision-makers and ultimately contributed to the radicalisation of the countryside in $1917-18 .^{53}$

Finnish legislators who sought solutions to the problems of tenancy certainly looked for models from other countries, not least from Ireland. The Irish land struggle and its confluence with the national movement had gained considerable exposure in the Finnish press during the Land War, and this interest continued at the beginning of the twentieth century. ${ }^{54}$ A case in point was a widely circulated article, published in 1907, that described the past of the Irish tenant farmers as a misery caused by freedom of contract and racial antagonism between Englishmen and Irishmen. The article, however, praised the recent Irish land acts as exemplary in improving the farmers' position. ${ }^{55} \mathrm{~A}$ similar stance was taken in J. N. Reuter's report on Irish agrarian legislation, which he compiled after a research visit to Ireland for the Agrarian Committee appointed by the Finnish Senate. Reuter concluded that the land act of 1903 had, in particular, advanced the formation of an independent farmer class, raised the standard of living and mitigated

${ }^{53}$ Peltonen, 'Epävarmuus', pp 319-24; Stephen Ball, 'Crowd activity during the Irish Land War, 1879-90' in Peter Jupp and Eoin Magennis (eds), Crowds in Ireland, c. 1720-1920 (Houndmills, 2000), p. 219.

${ }^{54}$ Länsi-Suomi, 29 Nov. 1879; Suomalainen Wirallinen Lehti, 17 Nov. 1881; Päivälehti, 19 Feb. 1903. See also Andrew Newby, “The cold northern land of Suomi”: Michael Davitt and Finnish nationalism' in Journal of Irish and Scottish Studies, vi, no. 1 (2012), pp 79-80.

55 Tampereen Sanomat, 15 May 1907; ibid., 17 May 1907. 
the unrest in the Irish countryside. ${ }^{56}$ Despite these opinions, however, the legislators felt that the Irish land reforms violated property rights in a way that would be unacceptable in Finland. The Finnish land lease acts of 1902 and 1909, therefore, remained more conservative than the Irish ones with regard to advancing tenants' interests. ${ }^{57}$

Eventually, it was only after the Civil War that the land lease question was solved in Finland: a new act in 1919 extended the tenants' right to buy out the lands they cultivated. As a result, over 90,000 tenant farmers and cottagers became independent farmers. ${ }^{58}$ The impact of this act resembled the Irish Wyndham act of 1903 , which had cemented the move towards owner-occupancy in Ireland. ${ }^{59}$ All in all, the expansion of owner-occupancy started earlier and lasted longer in Ireland than in Finland, but in both cases, tenant farmers had largely turned into freeholders by the late

${ }^{56}$ J. N. Reuter, Den nyare Agrarlagstiftningen i Storbritannien och Irland (Åbo, 1907), pp 227-8. Julio Reuter was a linguistics expert, professor of Sanskrit at the University of Helsinki, and prominent Finnish nationalist. He was particularly active in promoting Finland's image as a distincitve nation abroad. See also Newby's article in this issue. ${ }^{57}$ Rasila, Suomen torpparikysymys, pp 156, 206-08.

${ }^{58}$ Eino Jutikkala, 'Peasant movements and agrarian problems in Finland from the end of the XIXth century to second world-war' in Cahiers internationaux d'histoire économique et sociale, vii (1976), pp 84-5.

${ }^{59}$ Winstanley, Ireland, pp 40-41. See also, Philip Bull, 'The significance of the nationalist response to the Irish land act of 1903', I.H.S., xxviii, no. 111 (May 1993), pp 283-305. 
1920s. This large landholding class of farmers, many on non-productive holdings, was to have a long-lasting effect on the economy and politics of both countries.

What then was the impact of land-related protest movements on the expansion of owner-occupancy in Finland and Ireland? On the one hand, the intense rural restlessness during and after the Land War undoubtedly facilitated legislative reforms in Ireland. By contrast, in Finland the relative peacefulness of the countryside until the general strike of 1905 slowed down the need for rapid reforms, even if the problems related to landownership and tenancy were widely recognised early on. It was only the mass mobilisation of 1905-07, and eventually the revolutionary period of 1917-18, that truly compelled the politicians to solve the land question in Finland. One can speculate that had there been a wide-scale mobilisation of the Finnish rural lower classes during the 1880 s or 1890 s, the legislative reforms that followed might have been more radical in the first place. On the other hand, it is noteworthy that rural restlessness in Ireland had not been extinguished by the series of land acts in the late-nineteenth and earlytwentieth centuries. After the Land Law (Ireland) Act, 1881, for example, rural labourers vented their dissatisfaction increasingly on tenant farmers, whom they blamed for neglecting the workers' demands and treating their workers as shabbily as the landlords. ${ }^{60}$ There were also constant tensions between peasants and graziers, which led

${ }^{60}$ P. G. Lane, 'Agricultural labourers', pp 80-84; Boyle, 'Irish rural labourer', pp 32931. 
to public rallies and occasional violence, particularly after the land act of $1903 .{ }^{61}$ The rural unrest reached its peak in the revolutionary period from 1919 to 1923, during which landowners were exposed to even more vigorous attacks than during the previous decades. ${ }^{62}$ Thus, the series of land acts between 1882 and 1909 ultimately failed to extinguish social tensions within the rural population despite their success in abolishing landlordism.

IV

The activity of the Irish crowds who participated in agrarian agitation during the Land War had many parallels with the earlier protest movements of the late-eighteenth and early-nineteenth centuries. ${ }^{63}$ Stephen Ball points out, however, that the Land War also brought new features to the repertoire of collective action in Ireland. First, the Land League and National League used mass meetings and demonstrations to advance their programmes in an unprecedentedly systematic way both regarding the quantity of meetings and the length of the campaigns. Second, the Land League leaders encouraged

${ }^{61}$ David S. Jones, 'The cleavage between graziers and peasants in the land struggle, 1890-1910' in Clark \& Donnelly (eds), Irish peasants, pp 381-4; Patrick Cosgrove, The ranch war in Riverstown, Co. Sligo, 1908 (Dublin, 2012).

${ }^{62}$ Terence Dooley, 'Landlords and the land question, 1879-1909' in Carla King (ed.), Land, famine and culture in Ireland (Dublin, 2000), p. 135; Campbell, Land and revolution, p. 280. See also, Emmet O'Connor, A labour history of Ireland 1824-1960 (Dublin, 1992), pp 99-100, 112-3.

${ }^{63}$ See Clark \& Donnelly (eds), Irish peasants, pp 25-35. 
the crowds to employ restrained and disciplined forms of resistance. Together with the less aggressive style of policing adopted by the authorities, this contributed to the relative peacefulness of the protests in comparison with the disturbances of the early nineteenth century. Thus, in spite of numerous violent confrontations during the Land War, the risk of serious violence was impeded by the moderation of both parties of the protests. $^{64}$

The third distinctive feature of collective action during the land struggle was boycotting, that is, the social ostracism of individuals who did not conform to the Land Leaguers' objectives. Although the Land Leaguers did not invent boycotting as a social practice, they turned it into an effective part of an organised political project and stimulated the rapid adoption of the term 'boycott' across the world. ${ }^{65}$ Boycotting often involved intimidation, and it was sometimes accompanied by moonlighting, armed raids against tenants and labourers who had acted against the will of the Land League or who were warned about doing so. ${ }^{66}$ A well-known report by Paschal Grousset (1888) described how moonlighters had retaliated against a man who had accepted work on a

${ }^{64}$ Ball, 'Crowd activity', pp 213, 229-38, 241.

${ }^{65}$ On boycotting as a transnational political practice, see te Velde, 'Political transfer', pp 212-15. In Finland, Swedish-language newspapers used the term 'boycott' in their coverage of Irish events as early as 1880 (Morgonbladet, 18 Dec. 1880). See also Newby, in this issue, on its earlier political associations with Ireland, pp 00-00. ${ }^{66}$ Ball, 'Crowd activity’, p. 214. For moonlighting, see also Donnacha Seán Lucey, Land, popular politics and agrarian violence in Ireland: the case of county Kerry, 1872-86 (Dublin, 2011). 
boycotted farm by first cutting the tails off his cows and later mutilating his ears with a razor. ${ }^{67}$ Similar reports about violent acts or even murders committed by moonlighters appeared occasionally in newspapers, and they were effective in scaring people from disobeying the demands of the Land League and National League.

What was also new in the popular protests during the Land War was the effective use of the provincial press in boosting mobilisation. The success of the Land League owed much to a network of communications dependent upon the press, which heightened the impact of public oratory and spread the news of branch meetings and resolutions among an increasingly literate rural populace. The close link between the provincial press and the land movement derived from the fact that many of the newspapermen were themselves active Land Leaguers, who openly used their papers to promote the league's policies and to attack its opponents. ${ }^{68}$

In the Finnish countryside, the repertoire of collective action also changed between the 1880s and 1910s. As mentioned, traditional forms of political activity such as petitioning the government and spreading rumours about land redistribution were still in use, but they were gradually accompanied and superseded by new associational forms of collective action such as strikes, mass meetings and demonstrations. The rise of these

${ }^{67}$ Philippe Daryl [a pseudonym for Paschal Grousset], Ireland's disease: notes and impressions (London, 1888), pp 126-8.

${ }^{68}$ Marie-Louise Legg, Newspapers and nationalism: the Irish provincial press 1850 1892 (Dublin, 1999), pp 119-22, 138-47; Oisín Moran, ‘Thomas Stanislaus Cleary (1851-98): Land League leader and campaigning newspaper editor' in Casey (ed.), Defying, pp 100-13. 
new forms of action was closely intertwined with the spread of mass organisations such as temperance societies and workers' associations. Furthermore, the rise of the labour press with its network of rural correspondents improved the access of the rural working class to the printed media from the 1890s onwards. As in Ireland during the Land War, the press became a powerful tool for the Finnish labour movement in promoting its programme and organising the rural population. ${ }^{69}$ This was exemplified by how the labour press turned the violent evictions of Laukko manor's tenants in the winter of 1907 into a massive media event that boosted the socialists in the following parliamentary election. ${ }^{70}$

The revolutionary period of 1905-06 can be seen as a particular landmark in the transformation of Finnish rural political participation. On the one hand, the turbulence contributed to rural workers' militancy, which is reflected in the series of strikes in agriculture and the formation of 'red guards' by some workers' associations. On the other hand, the militancy was soon cushioned by the suffrage reform of 1906, which brought universal and equal suffrage to both men and women in parliamentary elections. Owing to the reform, the number of qualified voters was suddenly multiplied tenfold. In this climate of rapid change, the parliamentary election of 1907 was anticipated by voters as a revolutionary event, after which the long-awaited land reform

${ }^{69}$ Sami Suodenjoki, 'Kansalaisyhteiskunnan ja Suomen ideat, liikkeet ja julkisuudet' in Kari Paakkunainen (ed.), Suomalaisen politiikan murroksia ja muutoksia (Helsinki, 2012), pp 68-9.

${ }^{70}$ Rasila, Suomen torpparikysymys, pp 379-83. 
would finally materialise. ${ }^{71}$ This strong belief in the power of casting the ballot, however, faded away in the following years as the parliament failed to introduce rapid reforms due to its repeated dissolutions by the tsar. When a parliament with a socialist majority was dissolved in the summer of 1917, the popular disillusionment eventually erupted in the form of rioting and the arming of workers' militias both in cities and the countryside.

Unlike in the case of the Irish land movement, little research has been devoted to the use of clandestine collective action such as boycotting and moonlighting by Finnish rural people in the early-twentieth century. This may, of course, simply result from the scarcity of such activity. There is, however, evidence that during some agricultural strikes and eviction processes, rural workers organised boycotts against strike-breakers or land-grabbers. Moreover, court records reveal episodes such as the ones in Urjala, where a few organised rural labourers maimed a row of lime trees planted by a local landlord and defecated in the landowner's sauna at night. ${ }^{72}$ It is questionable, however, whether singular offences of this kind can be considered deliberate 'protests' or

${ }^{71}$ Hannu Soikkanen, Kohti kansan valtaa 1: 1899-1937 (Helsinki, 1975), p. 87; Risto

Alapuro, 'The construction of the voter in Finland, c. 1860-1907' in Redescriptions: Yearbook of Political Thought and Conceptual History, no. 10 (2006), pp 52-3, 58-60; Matias Kaihovirta, Oroliga inför framtiden: en studie av folklig politisk agerande bland bruksarbetarna i Billnäs ca 1900-1920 (Helsinki, 2015), pp 229-41.

${ }^{72}$ Suodenjoki, Kuriton suutari, pp 225-7, 230, 254-5. 
'resistance' against the landowner. ${ }^{73}$ On the whole, the organised use of direct actions such as plant or animal maiming, sabotage or arson was hardly as common among the Finnish rural people as it was in Ireland, if the revolutionary period of 1917-18 is excluded. ${ }^{74}$

\section{V}

The land movements in Finland and Ireland took radically different political courses during the period under examination. The crucial difference concerned the impact of two dynamic 'civic religions', nationalism and socialism, on land agitation. In Ireland, the Land War became a pivotal period in linking the land movement to the Irish nationalist movement. As rural restlessness grew, the Nationalist Party was able to convince the rural protesters that it had the means and the intent to solve the land question. Hence, the foundation of the Land League in 1879 provided agrarian

${ }^{73}$ For the danger of going too far with the concept of 'everyday resistance', see Katrina Navickas, 'What happened to class? New histories of labour and collective action in Britain' in Social History, xxxvi (2011), p. 203.

${ }^{74}$ The acts of sabotage committed in Finland in 1917-18 have received little scholarly attention, unlike the acts of political violence. Nevertheless, historiography mentions several instances of arson of manors, farmhouses and churches, not to mention innumerable minor infractions, committed by the Reds during the Civil War. See, e.g., Jaakko Paavolainen, Poliittiset väkivaltaisuudet Suomessa I: 'punainen terrori' (Helsinki, 1966). 
radicalism with a political orientation and made home rule essential to the agrarian issue. $^{75}$

Ultimately, the Land League and its less radical successor, the Irish National League, represented the interests of middle-class farmers rather than the rural proletariat. Nevertheless, they were able to absorb the protest movements of agricultural labourers and small farmers in the 1880s. Even though agricultural labourers formed their own organisations such as the Labour League to advance improvements in employment, housing and access to land, these organisations remained short-lived and dependent upon the middle-class nationalist movement. Thus, rural labourers remained politically marginalised, as the nationalist politicians delivered little to them despite their repeated promises of improvements. ${ }^{76}$

By contrast, in Finland the nationalist party was much less successful in organising tenants and agricultural labourers to support political nationalism in the late nineteenth century. This had to do with the Finnish nationalists courting the landowning farmers and their consequent reluctance to present land reforms that would collide with the landowners' interests. The reluctance continued even after the collection of the Great Address in 1899, during which tenant farmers and rural labourers had used the political crisis between Finland and Russia to protest against their treatment by landowning farmers. In this respect, the greater levels of freehold property in Finland

\footnotetext{
${ }^{75}$ Patrick O’Mahony and Gerard Delanty, Rethinking Irish history: nationalism, identity and ideology (Houndmills, 1998), p. 88.

${ }^{76}$ Pádraig G. Lane, 'The Land and Labour Association, 1894-1914' in Journal of the Cork Historical and Archaeological Society, xcviii (1993), p. 90.
} 
stand out as a factor that seems to have inhibited the development of cross-class alliances in the countryside. In Ireland, the conditions for joint political action between farmers and workers were more favourable, although these alliances often proved contentious.

One factor behind the ability of Irish nationalists to garner support from landless workers was their strengthening position in local government. At the time of the Land War, nationalists had gained control of many local relief agencies and used them to dispense welfare and patronage along political lines. This nationalist control of welfare provision did strengthen class collegiality and obscure social dissonance within the rural population during key points in the land struggle. ${ }^{77}$ In Finland, the situation was different, although the farmers' influence on local welfare policies increased as well when they began to take control of local bodies following the government reforms of the 1860s. At the same time, however, the rapid growth of the rural proletariat contributed to an increase in the number of people in need of relief. ${ }^{78}$ Consequently, poor relief distribution caused constant dissatisfaction among the landless, who were

${ }^{77}$ Donnacha Seán Lucey, 'Power, politics and poor relief during the Irish Land War, 1879-82' in I.H.S., xxxvii, no. 148 (Nov. 2011), pp 584-98; William L. Feingold: 'Land League power: the Tralee Poor-Law election of 1881' in Clark \& Donnelly (eds), Irish Peasants, pp 285-310.

${ }^{78}$ Jouko Jaakkola, Panu Pulma, Mirja Satka and Kyösti Urponen, Armeliaisuus, yhteisöapu, sosiaaliturva: suomalaisen sosiaalisen turvan historia (Helsinki, 1994), pp $121-33$. 
largely excluded from influencing local policies due to the restricted franchise up until the subsequent local electoral reform of 1917.

Another factor affecting cross-class alliances was that the independent organisation of tenants and rural workers started significantly later in Finland than in Ireland. This is noteworthy, given that many voluntary associations such as farmers' societies, temperance societies and youth societies certainly gained ground in the Finnish countryside from the 1870 s onwards. Many of these associations welcomed tenant farmers and farm workers as members, but their leaders represented the urban and rural upper class and regarded the lower social groups more as targets of education than as equal actors in the associations. ${ }^{79}$ Thus, these associations did not provide tenants or workers with an arena for voicing their grievances any more than the newspapers and prominent political groups did in the 1880s and 1890s.

From around the turn of the twentieth century, Finnish rural people came increasingly into contact with the socialist movement. Socialist ideas were promulgated by the agitators and emergent newspapers of the Finnish Labour Party (from 1903, Sosialidemokraattinen Puolue Suomessa, abbreviated as S.D.P.). The socialist agitation found resonance particularly in south-western Finland, where manors were most numerous, agriculture was most commercialised, and the tensions between landowners and their tenants were most visible. In many localities, the eviction of tenants or the tightening of rental terms by landowners produced conflicts, which were eagerly utilised by labour activists. The activists realised that in order to gain mass support, the

${ }^{79}$ Ilkka Liikanen, Fennomania ja kansa: joukkojärjestäytymisen läpimurto ja Suomalaisen puolueen synty (Helsinki, 1995), pp 237-8. 
Labour Party needed to respond to the rural proletariat's hope of access to land. Hence, they strove tactically to adapt Marxist ideas on agriculture to suit the local circumstances. ${ }^{80}$ In this, the Finnish socialists followed the same path as their Scandinavian and German counterparts in seeking to win over the rural population by adopting a favourable stance towards small-scale farming. ${ }^{81}$

Despite the favourable social conditions, however, the progress of the socialist movement proved sluggish in the Finnish countryside. Besides the long distances and the lack of skilled local organisers, organisation was hampered by rural workers' fears of discrimination by local power holders who opposed socialism. Another obstacle was rural religiosity, even though socialist activists tried to reassure their potential supporters that socialism was compatible with Christianity. ${ }^{82}$ In part, religiouslyinspired suspicion of socialism stemmed from the activity of Lutheran clergymen, many of whom campaigned against labour radicalism along similar lines to the Catholic church in Ireland. ${ }^{83}$

${ }^{80}$ Soikkanen, Sosialismin tulo, pp 124-30; Suodenjoki, Kuriton suutari, 140-44.

${ }^{81}$ See Gerd Callesen, 'Denmark' in Marcel van der Linden and Jürgen Rojahn (eds), The formation of labour movement, s 1870-1914: I(Leiden, 1990), pp 147-8; Annette Thörnquist, Lönearbete eller egen jord? Den svenska lantarbetarrörelsen och jordfrågan 1908-1936 (Uppsala, 1989), pp 59-60; Francis Sejersted, The age of social democracy: Norway and Sweden in the twentieth century (Princeton, 2011), pp 132-5. ${ }^{82}$ Suodenjoki, Kuriton suutari, pp 163-8; Soikkanen, Sosialismin tulo, pp 195-207. ${ }^{83}$ See Emmet Larkin, 'Catholicism and Socialism in Ireland' in Church History, xxxiii (1964), pp 462-83. 
It was not until the general strike of 1905 that the preconditions for rural workers' political mobilisation changed fundamentally in Finland. During the months following the strike, thousands of workers and tenants across the countryside poured into local socialist associations. By the end of 1906, there were at least 937 branch associations of the S.D.P., with more than 85,000 members in total. Almost 70 per cent of the members came from the countryside. ${ }^{84}$ The scale of support for the S.D.P. among the Finnish agrarian population was exceptional in Europe. What made it possible was the parliamentary reform, which seemed to bring within reach all of the social reforms yearned for by the tenants and landless workers. In this atmosphere, the S.D.P. seemed to be the political group most able to realise the long-awaited land reform in the parliament.

In the first parliamentary election with universal and equal suffrage, in 1907, the S.D.P. gained 37 per cent of the ballot in Finland. The strongest zones of support for socialism were not in the cities but in rural areas, mostly in south-western Finland. In the parish of Humppila, no less than 84 per cent of voters backed the socialists, and in the former strike area of Jokioinen, the socialists gained 77 per cent of the vote. ${ }^{85}$ Such huge percentages imply that not only agricultural workers but also large numbers of tenant farmers aligned themselves with the S.D.P. Despite considerable differences in social position, both these rural groups were essentially connected by political subjugation and therefore responsive to the socialists' promises. Particularly appealing to the tenant farmers was the socialists' requirement of forced cultivation, which meant

\footnotetext{
${ }^{84}$ Soikkanen, Sosialismin tulo, pp 338, 343.

${ }^{85}$ Suomen virallinen tilasto XXIX, vaalitilasto 1 (1907), table II.
} 
that landowners had to yield up their uncultivated arable land to a tenant farmer for cultivation on a long-term, inheritable lease. ${ }^{86}$ On the other hand, the socialists struggled most in areas where the proportion of tenant farmers and agricultural workers was low in comparison to freeholders. Hence, the S.D.P. received less than a quarter of the vote in the provinces of Vaasa and Oulu. In these provinces, the recently established Agrarian League challenged the socialists strongly in canvassing rural voters. ${ }^{87}$

The charm of socialism among rural voters proved to be a durable phenomenon, as the SDP consolidated their rural support in the following elections. The success culminated in the election of 1916 when the S.D.P. won 103 out of 200 seats. The socialist majority also stimulated party membership, which peaked in the revolutionary year of $1917 .{ }^{88}$ After the bloody Civil War of 1918, the membership of the left-wing parties and their electoral support declined somewhat in rural regions. Partly, this was due to the land lease legislation introduced after the war, which turned thousands of tenants into freeholders. Another reason was that the growing pace of industrialisation drew landless people from the countryside to the cities. Nevertheless, the socialist

\footnotetext{
${ }^{86}$ On the demand for forced cultivation see Petri Jussila, Tilastomies torpparien asialla: Edvard Gyllingin maatalouspoliittinen toiminta ja ajattelu suurlakon ja sisällissodan välissä (Helsinki, 2015), pp 104-11.

87 The Agrarian League had Finnish-nationalist origins and it sought to lessen class antagonism in the countryside, for example, through the emancipation of tenant farmers. Soikkanen, Sosialismin tulo, pp 285-6, 386-9.

${ }^{88}$ Soikkanen, Kohti kansan valtaa 1, pp 260-61.
} 
movement still retained strong support among the Finnish rural population by contemporary European standards.

In Ireland, the resonance of socialism in the countryside was strikingly modest in comparison to Finland. Certainly, socialist ideas had been adopted there early on by some Land League leaders such as Michael Davitt, who had connections to the British socialist movement that emerged in the 1880s. Regarding the land question, Davitt became a proponent of land nationalisation instead of peasant proprietorship, although during the Land War he shelved this idea, realising its meagre support among the rural population. Later he promoted land nationalisation openly and was therefore alienated from the leader of the nationalist movement, Charles Stewart Parnell, and from many of the tenant farmers as well. ${ }^{89}$ The problem of reconciling Marxist views of agriculture with the expectations of landless people was not the only reason for the socialists' poor success in the Irish countryside. The preconditions for the mass support of socialism were also weakened by the structural frailty of urban labour in the southern part of the country. In addition to this, the patriarchal employment relations on farms and the pressure of local communalism hindered landless labourers from organising effectively and sustaining their organisations. Moreover, many of those considered 'agricultural labourers' worked on family farms where ties of family may have blurred their sense of class affiliation. ${ }^{90}$

${ }^{89}$ Fintan Lane, 'Michael Davitt and the Irish working class' in Lane and Newby (eds), Michael Davitt, pp 75-98.

${ }^{90}$ O’Mahony \& Delanty, Rethinking, p. 89; Fitzpatrick, Politics, pp 237-40. 
In Finland, these hindrances to the rise of socialism in the countryside were actually not very different from Ireland. Therefore, one cannot overstate the importance of the ability of Irish nationalist politicians to incorporate agrarian radicalism into the nationalist fold after the Land War. This incorporation proved effective in preventing agrarian radicals from moving leftwards. Even though socialist ideas may have appealed to many radicals, they 'were often nationalists first and trade unionists second'. Hence, they were reluctant to defy the nationalist consensus, allowing the nationalist movement to absorb the rural labourers' organisations without essentially compromising its overall aims. ${ }^{91}$ This stood in sharp contrast to Finland, where the socialist movement forcefully challenged farmer-based nationalism and resonated with the rural working class by presenting an alternative version of nationalism that emphasised the extension of civil rights. ${ }^{92}$

VI

Taken together, the Nationalist Party in Ireland and the S.D.P. in Finland shared the ability to provide plausible solutions to the land question during a formative period in national history, that is, the Land War in Ireland and the general strike in Finland. Nonetheless, the character of the land movements in both countries was very different, notably in relation to ideological basis, levels of violence, protesters' relationships with

${ }^{91}$ O’Mahony \& Delanty, Rethinking, pp 89-90.

${ }^{92}$ Pertti Haapala, 'The expected and non-expected roots of chaos: preconditions of the Finnish Civil War' in Tuomas Tepora and Aapo Roselius (eds), The Finnish Civil War 1918: history, memory, legacy (Leiden, 2014), p. 30. 
central authorities, and the pace of consequent legislative reform. These differences stemmed partially from the different relationships with the respective imperial centres and the divergent patterns of land ownership in Finland and Ireland. However, closer scrutiny of other factors, such as religion and church activity, emigration, and the nature of agricultural production and other rural industries, might also provide fruitful premises for comparative analysis.

The comparison of Finland and Ireland elucidates important issues relating to transnationalism and regionality. First, the different political paths taken by the land movements in each country were clearly affected by the fact that international socialism was still weak in the 1880s in comparison with the early-twentieth century. Second, Finnish socialism was obviously heavily influenced by the revolutionary movements in Russia, whereas in Ireland the Russian developments had a far more limited impact even during the revolutionary period in the 1910s and early 1920s. That said, the early Finnish socialists were not tightly bound to Russian socialism either, for they looked for solutions to the land question from Germany and Scandinavia rather than from their Russian counterparts. Regarding the diverse strands of socialism, it is also noteworthy that the focus of British socialism on urban and industrial relations lessened its relevance to the Irish land movement. Indeed, it was militant Fenianism, often emanating from Irish America, that had a greater impact on Irish land agitation than socialism.

Hence, one can conclude that the imperial or regional contexts of the United Kingdom and Russia are not the sole explanations for the characteristics of land agitation in Ireland and Finland. Instead, the land movements had a trans-European and transatlantic dimension as well, which was manifested, for example, in the diffusion of 
the forms of collective action, personal contacts, and the spread of legislative reforms across the borders. As the influence of the Irish land acts on Finnish legislators and the keen interest of Finnish newspapers in the Irish Land War indicate, the land movements around Europe did not develop in isolation, but were intrinsically interconnected. 